\title{
「送電用鉄塔の風荷重指針 (案)」の基本的考え方
}

Basic Concept of "Recommendations of Wind Loads for Overhead Transmission Towers"

$\begin{array}{cr}\text { O大熊 武司 } & \text { 石川 } \\ \text { Takeshi OHKUMA }^{1)} & \text { 智巳 } \\ & \text { Tomomi ISHIKAWA }\end{array}$

\section{1.はじめに}

送電用鉄塔の設計にあたっては，台風等の風荷重で 設計荷重が決められることが多く，また，近年の台風 による損壊例の発生，大規模化，基数の増大などによ り，有事の際の社会的影響度の点功，合理性を兼称 備えた高い信頼性が求められるようになってきている. 一方で, 近年の構造設計における「性能設計の考え方」 への転換，既存鉄塔の安全性診断・補強等への対応な ど，荷重効果の実況の評価法も必要な状況となってい る.

電気事業連合会では，平成 3 年 9 月の台風 19 号 による送電鉄塔の設備被害をきっかけとして，送電 鉄塔の耐風設計法に関する検討を進めてきた. 本報 告はこれまでの研究活動の概要とその成果である

「送電用鉄塔の風荷重指針（案）・同解説」の基本 的考え方を紹介する.

\section{2. 近年の架空送電設備の耐風安全性に関する研究動} 向

台風 9119 号による事故後の被害調査を踏まえ， 全電力会社, 学識経験者および (財) 電力中央研究 所により「局地風対策研究推進委員会 (委員長 : 筆 者 (大熊武司)，平成 4 年 10 月～平成 11 年 3 月)」 が設置され，(1)局地風の実体把握と構造の解明，(2) 局地風の実用的解析予測手法, (3)送電設備の風応答 特性の把握と合理的な設計手法の確立を主な課題 として研究が開始された. 本研究プロジェクトでは, 九州試験線（既設 $66 \mathrm{kV}$ 送電線），四国試験線（3 基 2 径間, $500 \mathrm{kV}$ 送電線) による風および風応答観測 (Photo 1 参照) とその分析, 地形影響を評価するための数值 流体解析コードの開発, 鉄塔・架涉線連成系の動的応 答解析手法の開発, および等価静的風荷重算定法の検 討を行った.これらの成果は, 既存の設計法を補完す

1) 神奈川大学工学部建築学科 教授

Professor, Kanagawa University

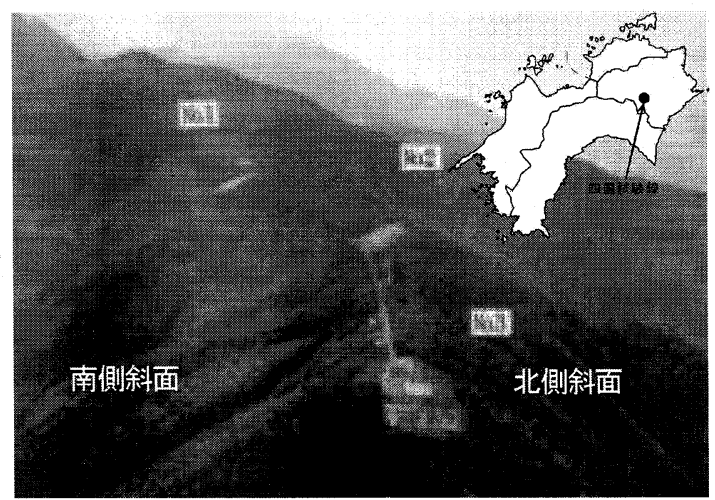

Photo 1 Shikoku Test Line

るものとして「特殊地形における送電用鉄塔の風荷重 指針 (案)」 ${ }^{1)}$ によめられた。

引き続き，上記指針案の一般地形への拡張，より合 理的な設計手法の確立を目指して，「而風設計合理化委 員会 (委員長 : 筆者 (大熊武司), 平成 11 年度～平成 13 年度)」を設置し, 研究活動を継続した. 本委員会 では, 風向別風速の導入, 風荷重評価法の精緻化（風 荷重の組み合わせ法)を中心に検討が行われた. また， 数值流体解析コードや風荷重評価式の信頼性を保障す るために, 2 山地形周りの気流場の測定 (Photo 2) や, 架渉線風応答に関する風洞実験・フィールド実験

（Photo 3）を実施し，バックデータの蓄積に努めた. さらに，一連の成果を取りまとめ，局地風指針案の適 用範囲を拡大した「送電用鉄塔の風荷重指針 (案) ・同 解説」2)を策定した。

\section{3.「送電用鉄塔の風荷重指針（案）」の基本的考え方}

3. 1 特 徵 2

本指針案の技術的な特徴は以下の通りである.
2) (財) 電力中央研究所 地球工学研究所

Central Research Institute of Electric Power Industry 


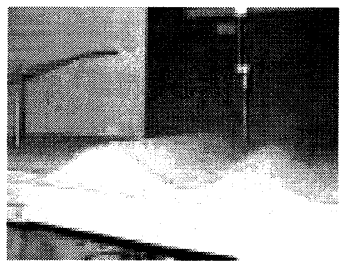

(Two-dimensional hills)

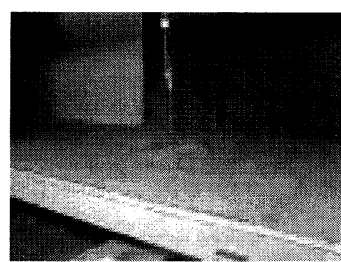

(Three-dimensional hills)
Photo 2 Measurements of turbulent flow

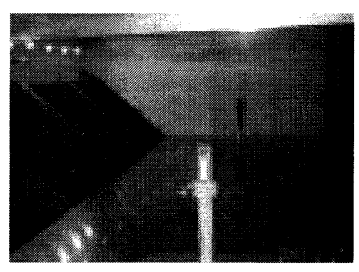

(Wind Tunnel Test)

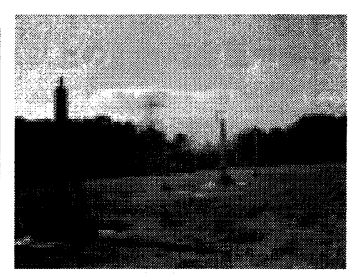

(Field Test)
Photo 3 Measurements of cable gust response

(1) 技術基準の性能規定化，国際化ならびに技術環境 のコンピュータリゼーションの進展に配慮した.

(2) 最新の統計データ, シミュレーション技術を活用 して風向別基本風速を策定するとともに，ガス卜 影響係数法に基づく荷重評価体系とした.

(3) 数值シミュレーション技術を積極的に導入し，そ の適用にあたっての留意点を整備した.

Fig.1 に本指針案の風荷重算定フローを示す。また, 以下に，設計風速，設計用風荷重の算定における基本 的考え方を概説する.



Fig.2 Fig.1 Flowchart of design wind load estimation

\section{2 設計風速 ${ }^{2}$}

設計風速は，8風向の風向別基本風速に当該地点の 地表面粗度, 小地形による増速効果および気象学的増 速効果を考慮して，5度ピッチ， 72 風向定めるものと した．風向別基本風速の策定にあたっては，気象官署 観測データの成因（台風と非台風）による区別，台風 モデルを用いたモンテカルロ・シミュレーション，気 象官署值とのキャリブレーションなどのアイディアを 採用した. また，その再現期間は，「風向別に評価した ことによる全体としての安全性については, 従来と同 程度のレベルを維持すること」を基本方針として定め た。

次に，小地形の影響評価については，数值流体解析 の利用のほかに, 2 次元崖状地形の増速率データベー スに基づく簡易増速率算定法を用意した. 気象学的影 響評価については, 現状では取得可能なデータに限界 があることから，具体的数值あるいは評価手順を明示 することはできなかったが，実況に応じ，適切な調査 研究に基づき，その影響を評価するものとした.

\section{3 設計用風荷重 ${ }^{2)}$}

設計用風荷重は, 設計用速度圧に, 風力係数, 受風 面積, ガス卜影響係数を乗じて算定される. ここで, ガスト影響係数法の適用にあたり, 構造特性の異なつ たサブシステム (鉄塔, 架渉線など) で構成されてい ることに配慮する必要がある. 本指針案では, 鉄塔と 架渉線の動的連成効果は小さいことを前提に，鉄塔風 圧荷重, 架渉線風圧荷重, がいしおよひ架線金具風圧 荷重, 架涉線張力荷重に分類し，各々の風荷重を個別 に評価するものとした．また各々の風荷重から水平角 度による座標変換により, 鉄塔軸に対する鉛直荷重, 線路直交方向荷重，線路方向荷重を算定することによ り，鉄塔設計一の適用を考慮した風荷重評価法として いる. さらに，鉄塔風王荷重および各架涉線風荷重の 変動成分の組み合わせ方法として，任意の風向，架線 状態に適用できる非同時性低減係数を定式化し，その 值を適用した.

\section{4. 結 び}

本報告では，近年の送電用鉄塔の耐風設計法に関す る研究動向と「送電用鉄塔の風荷重指針 (案)」の概要 について紹介した．現在，実務的な観点から簡便法の 構築, 設計省力化ツールの整備を進めている.

謝辞

本研究を実施するにあたりご指導，ご助言いただいた関係者 各位に深く感謝扎します。

\section{参考文献}

1）大熊武司他，特殊地形に㧍ける送電用鉄塔 - 架涉線連成系 の而風設計に関する研究（その1）局地風対策研究成果の 取りまとめ, 日本風工学会論文集, 第 82 号, pp.39-48, 2000

2）大熊武司他，風向別風速を用いた送電鉄塔の耐風設計法に 関する研究一「送電用鉄塔の風荷重指針(案)」の骨子一, 日本風工学論文集，第 98 号，pp.137-150，2004 
風向および地形影響を考慮した設計風速算定法

Design wind speed estimation method considering wind direction and topographic effect

○中村 秀治 ${ }^{1)}$

Hideharu NAKAMURA ${ }^{1)}$
山崎 智之 ${ }^{2)}$

石川 智巴 ${ }^{2)}$

Motoyuki YAMAZAKI $^{2)}$ Tomomi ISHIKAWA ${ }^{2)}$ Nobukazu TANAKA ${ }^{2)}$

\section{1 はじめに}

送電用鉄塔の合理的而風設計法の確立のためには, 建 設地点の風の風向特性と地形による影響を考慮した設 計風速の算定法を確立することが重要となる.ここでは, 而風設計合理化委員会 ${ }^{1)}$ で検討した設計風速の算定式と 風向別基本風速の概要, および小地形による風速の割り 増し係数について最近の検討を含め報告する.

\section{2 設計風速の算定式}

設計風速の算定にあたっては, 風向に敏感な送電用鉄 塔の特性を踏まえ，8風向の風向別基本風速に当該対象 地点の地表面粗度, 小地形の影響および気象学的増速効 果を考慮して 5 度ピッチ, 72 風向定めることとした.

設計風速 $U_{R}$ は, 基準高さ $z_{R}$ における 10 分間平均風 速を表し, 次式に示すとおりとした.

$$
\text { ここに, } \quad U_{R}=k_{1} k_{2} E U_{0}
$$

$U_{0}$ : 建設地点から $10 \mathrm{~km}$ 程度風上の風向別基本風速 $[\mathrm{m} / \mathrm{s}]$

で, 8 風向別に設定 (1 風向 45 度内は一定値).

$k_{I}$ : 鉄塔の基潐高さ位置における小地形による風速の割 り増し係数を表し， 5 度ピッチ， 72 風向別に設定. $k_{2}$ : 気象学的要因による風速の割り増し係数で, 8 風向 別に設定.

$E:$ 風速の鈶直分布係数で，建設地点対象風向の地表面 粗度に応じて定める (8 風向別に設定). なお, 地表 面粗度区分は, 対象風向前方 1 $2 \mathrm{~km}$ 程度の風上側 の状況を考慮して定める.

\section{3 風向別基本風速}

風向別基本風速 $U_{0}$ は，直近の地形による影響が $k_{1}$ に より評価されること, 風向特性を考慮することを勘案し て, 次のように定義した.

(1)粗度区分 II, 地上高 $10 \mathrm{~m}$ の 10 分間平均風速

(2) 8 風向別とし, 風向別再現期間 150 年に対する風速, ただし，全風向再現期間 50 年に対する風速を上限と する.

(3) $10 \mathrm{~km}$ 四方程度を代表する風速（大規模な地形影響を 考慮)

ここに, 上記で定義した風向別再現期間 150 年は, 対 象地点の風向特性と送電用鉄塔の荷重効果から, 鉄塔部 材の設計軸力に対して年超過確率 0.02 (従来と同程度の
レベル）を目標として定めたものである．また， $10 \mathrm{~km}$ 四方程度を代表する風速としたのは, 建設地点を中心と した $10 \mathrm{~km}$ 四方程度の領域においては, 小地形による割 り増し係数 $k_{1}$ で考慮し, それよりも遠方あるいは大規 模な地形の影響については, 基本風速として配慮してい ることを明確にするためである.

風向別基本風速に関しては, 風向別基本風速マップを 用意することとした. マップの作成にあたっては，まず 送電線の張力が気温の影響を顕著に受けることを踏ま え, 全国の気象官署の観測値を高温季, 低温季に分類し た. 次に高温季にあっては成因別（台風と非台風）に整 理するとともに, 台風データについては, 台風シミュレ ーションによる值を気象官署の観測值でキャリブレー ションする方法を提案し, 気象官署位置の風向別基本風 速を求めた. さらに, 風向別に大規模地形の影響を考慮 するため, 風洞実験 ${ }^{2}$ により精度を確認した $k-\varepsilon$ モデル による気流解析 ${ }^{3)}$ から得られる平均風速の水平方向分布 を気象官署間の内挿に用い, 気象官署の基本風速とのフ イッティングとスムージング処理を行うことにより, マ ップ化を図った. ただし，上述の解析方法では，大気の 温度勾配やコリオリカによる風速への影響などは考慮 されていないという課題を有している.

\section{4 小地形による風速の割り増し係数}

基本風速に考慮されていない数 $\mathrm{km}$ スケールの小地形 による風速の割り増し係数 $k_{I}$ の評価は, 増速率図を用 いて行うこととした. 増速率図は, 二次元崖状地形を対 象に $k$ - $\varepsilon$ モデルによる気流解析を行い, 地形周りの平均 風速の水平方向分布を入口部の風速分布で除し, 入口風 速に対する対象地点の風速の倍率として, コンタを描く ことにより作成した. 気流解析の条件は, 斜面の高さ $H$ を $200 \mathrm{~m}$, 入口風速は地表面粗度区分而のプロファイル, 地表面粗度区分をIII, 水平格子間隔は斜面部水平距離の $1 / 16$ とし, 鉛直格子間隔は下層 10 メッシュを $10 \mathrm{~m}$ ，そ れより上空 $10000 \mathrm{~m}$ までを 20 メッシュに分割した. ま た斜面の種類は勾配 5 度から 60 度まで 5 度刻みの 12 ケ ースとした. 地形のモデルを Fig.1 に, 気流解析によっ て求めた増速率図 ( $\theta=40 \mathrm{deg})$ の例を Fig.2 に示す. 解析結 果では, 斜面入口部では淀み域が生じて減速し, 崖上の エッジ部分では, ごく一部に 2.0 以上の大きな増速率が
1) 広島大学大学院 工学研究科 教授 Professor, Hiroshima University
2) (財) 電力中央研究所

Central Research Institute of Electric Power Industry 
生じているが, 1.0 未満は増速率 1.0 に, 2.0 を超える場 合は増速率 2.0 に補正して解析結果を用いた。これは, 風速の割り増し係数 $k_{1}$ では増速のみを評価し, また, 2.0 を超える極端に大きな值は, シャープなエッジを有 する解析モデルを用いた数值解析上の值であるという 認識によるものである.

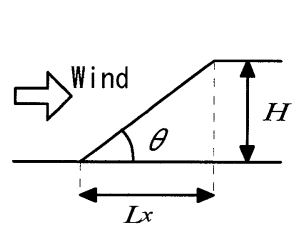

Fig.1 Topographic model for single slope

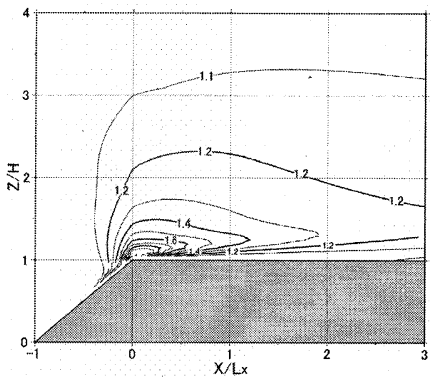

Fig. 2 Speed-up ratio for single slope 増速率図の適用にあたり, 地形の状況によっては単一 の斜面で評価しがたい場合, 特に風上側に斜面が複数存 在する場合に，地形をどのように評価すべきか，という 問題に直面する. これまで, 二つの斜面を有する地形 (以 下, 複合斜面という)の $k_{1}$ は, 直近の二つの斜面の各々 の増速率の積により評価するものとしていた. しかし, 気流解析によって求めた $k_{1}$ に比べて過大評価を与える ことから, 複合斜面による増速率図を作成することとし た. 複合斜面のモデル化にあたり，二つの斜面の勾配 $\theta_{1}, \theta_{2}$ と水平距離 $L_{x 1}, L_{x 3}$, および斜面間の距離 $L_{x 2}$ が主な パラメータとなる. 検討した地形のパラメータとその設 定值を Table 1 に示す. 気流解析の条件は, 二つの斜面 の高さの和 $H$ を $200 \mathrm{~m}$ ，地表面粗度区分を而とし，解析 メッシュは二斜面のスケールとその組み合わせに応じ て適切に定めた. 複合斜面の地形モデルを Fig.3 に, 求 めた増速率図 $\left(\theta_{1}=\theta_{2}=40 \mathrm{deg}\right)$ の例を Fig.4 に示す.

Table 1 Values of topographic parameter

\begin{tabular}{c|l}
\hline parameter & value \\
\hline$\theta_{1}(\mathrm{deg})$ & $5,10,15,20,25,30,35,40$ \\
\hline$\theta_{2}(\mathrm{deg})$ & $5,10,15,20,25,30,35,40$ \\
\hline$L_{x 2} / L \times 3$ & $1 / 4,1 / 2,1,2,4$ \\
\hline$L \times 1 / L \times 3$ & $1 / 4,1 / 2,1,2,4$ \\
\hline$L \times 2 / L \times 1$ & $1 / 16 \sim 16$ \\
\hline
\end{tabular}

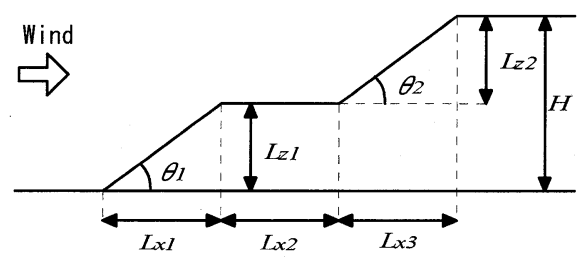

Fig.3 Topographic model for double slopes

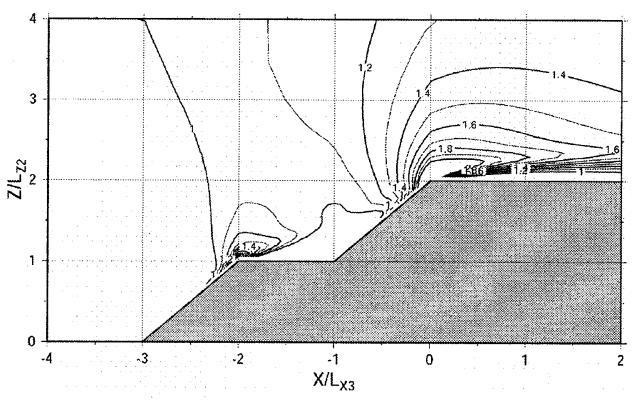

Fig.4 Speed-up ratio for double slopes

求めた単斜面および複合斜面の増速率図は, 設計に活 用することを目的に，データベース化を図るとともに， 任意の地点の $k_{l}$ を求めるためのツールを作成した.こ のツールは, 50m メッシュの地形デー夕を準備し, 緯度, 経度および構造物の基準高さを入力することで, 風上側 の斜面を評価し，適合する増速率データベースを参照す ることにより，水平方向 5 度刻みの $k_{l}$ を算定するもの である. 本ツールによって算定された $k_{1}$ は，実地形に よる気流解析結果との比較により, 概ね妥当な值を与え ることを確認した. なお，本手法は，風上側の地形を二 次元崖状地形と仮定して $k_{l}$ を求める簡便な手法である. このため, 風上側地形による遮蔽の影響や三次元的影響, および凹凸による境界層の発達の影響などを詳細に評 価したい場合は, 気流解析や観測などによるべきである.

\section{5 結 び}

送電用鉄塔の設計合理化を目的とした設計風速の算 定式, 風向別基本風速の概要, および二次元崖状地形の 気流解析データベースを用いた小地形による風速の割 り増し係数の評価法について報告した.

\section{謝 辞}

「而風設計合理化委員会 (平成 11 年 4 月～平成 14 年 3 月）」，「而風設計実用化検討会（平成 14 年 4 月～平成 17 年 3 月」(大熊武司委員長 (神奈川大学) ) の関係各 位に深く感謝いたします。

\section{参考文献}

1) 大熊武司, 中村秀治, 石川智巳, 本郷栄次郎, 渡辺敏緒, 篠田明秀，北嶋知樹 : 風向別風速を用いた送電鉄塔の耐 風設計法に関する研究一「送電用鉄塔の風荷重指針(案)」 の骨子一，風工学論文集，第 98 号，pp.137-150,2004.1

2)中村秀治, 石川智巳, 大熊武司, 田村幸雄, 田中伸和, 北嶋知樹 : 風向別基本風速マップ作成の試み，日本風工 学論文集, 第 97 号, pp.121-136,2003.10

3)南 浩二, 老川 進, 服部康男, 漆原育男, 石原 孟, 中村秀治, 田中伸和 : 風洞実験による 2 山地形周りの乱 流特性に関する検討，日本風工学論文集，第 98 号， pp.105-115,2004.1 
鉄塔・架涉線連成系の風荷重評価法の概要と観測值との比較による検証

Wind loads evaluation method for transmission tower-conductor system and verification results

○石川 智巳 ${ }^{1)}$

橋本 純也 ${ }^{1)}$

Tomomi ISHIKAWA $^{1)}$ Junya Hashimoto ${ }^{1)}$

\section{1.はじめに}

風向別風速と送電線路の構造特性を考慮した耐 風設計を実現するためには, 任意の風向に対する風 荷重を精度良く評価できなければならない.すなわ ち，風向に応じた鉄塔・架渉線連成系の動的効果を 考慮できる必要がある。このため，著者らは，ガス 卜影響係数法に基づき鉄塔風圧荷重, 架渉線風圧荷 重, 張力荷重といった個々の風荷重評価式を提案 ${ }^{1)}$ した.さらに，理論的，実験的考察に基づきこれら の荷重の組み合わせ方法を開発し，より実況に応じ た風荷重評価が可能となった.

本報告では, 本風荷重評価法の特徵を述べるとと もに，四国試験線観測值との比較検証例を示す.

\section{2. 設計用風荷重の分類}

本風荷重評価法では，風荷重を鉄塔風圧荷重，架 渉線風圧荷重，がいしおよび架線金具風圧荷重，架 渉線張力荷重に分類した (Fig.1 参照)。これらの風 荷重は, ガス卜影響係数法により算定することを基 本とし，風に対する構造物の最大応答值と同じ荷重 効果をもたらす静的な風荷重として与えられる.さ らに，これらの荷重から，水平角，高低差の補正を 行い鉄塔軸に対する鉛直方向荷重, 線路直交方向荷
重，線路方向荷重を算定することにより、鉄塔設計 に適用するものとした.

\section{3. 設計用風荷重の組み合わせ}

各風荷重について, 鉄塔軸に関する座標変換を行 い，平均成分についてはベクトル和，変動成分につ いては絶対值和を求め, 両者を組み合わせることに より，設計に必要な荷重が算定される。このとき， 各風荷重の変動成分については, それらの最大值が 同時に作用しないことを考慮するため, 非同時性低 減係数が乗じられる.ここで, 非同時性低減係数は, 理論的考察から誘導した各荷重閒の相関係数に基 づき定めている.

\section{4. 本評価法の妥当性検証}

以上に述べた風荷重評価法の妥当性検証を目的 に，四国試験線（3 基 2 径間）における過去の主要 な台風による張力, 軸力などの応答観測値と各台風 時の乱流統計量を入力值とした本評価法による計 算值の比較を行った。一例として, 台風 9807 号, 台風 9810 号時の南側老番 $\mathrm{C} 2$ 電線における架渉線風 圧荷重の最大值, ガスト影響係数の比較結果を Fig.2 に, 架渉線張力荷重の最大值の比較結果を Fig.3 に 示す。また，台風 9426，9514，9798，9719，9810，

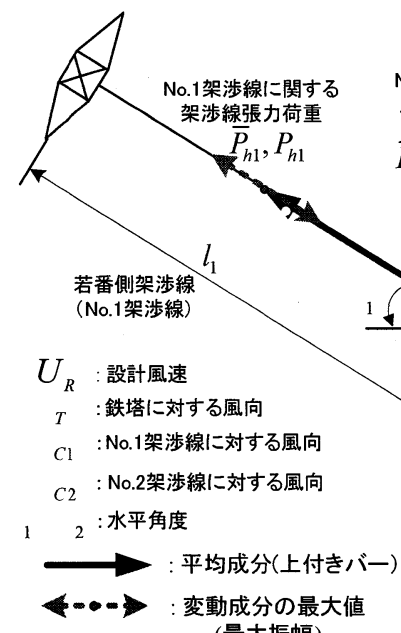

(最大振幅)

\section{線路直交方向}

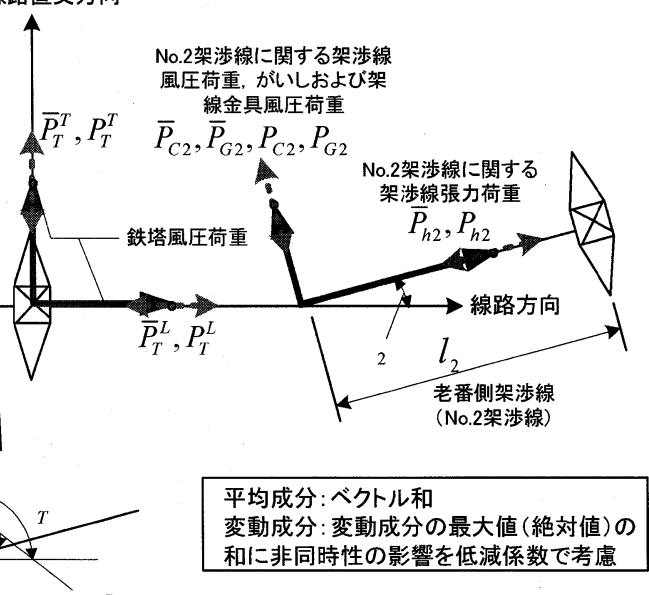

C2

Fig.1 Outline of Wind Loads

1)（財）電力中央研究所

Central Research Institute of Electric Power Industry 

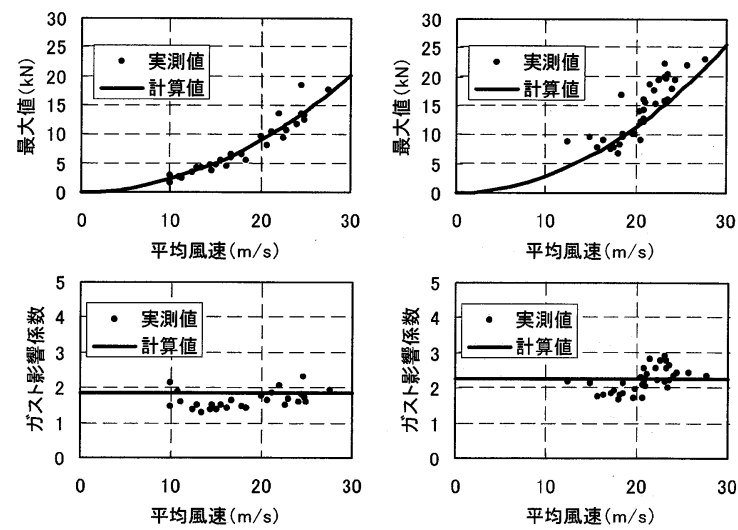

(a)Typhoon $9807(\mathrm{~N})$

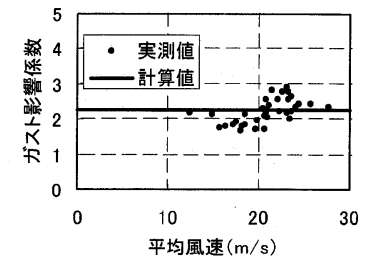

(b) Typhoon $9810(\mathrm{~S})$

Fig.2 Wind force of cable

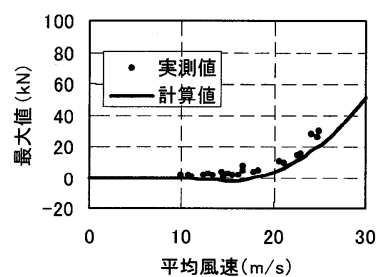

(a)Typhoon $9807(\mathrm{~N})$

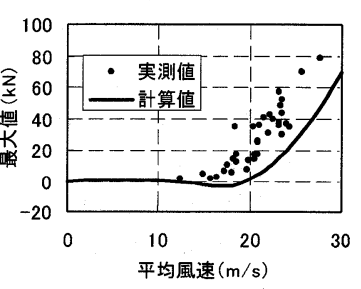

(b) Typhoon 9810(S)

Fig.3 Tension Force of cable

観測值 $[\mathrm{kN}]$

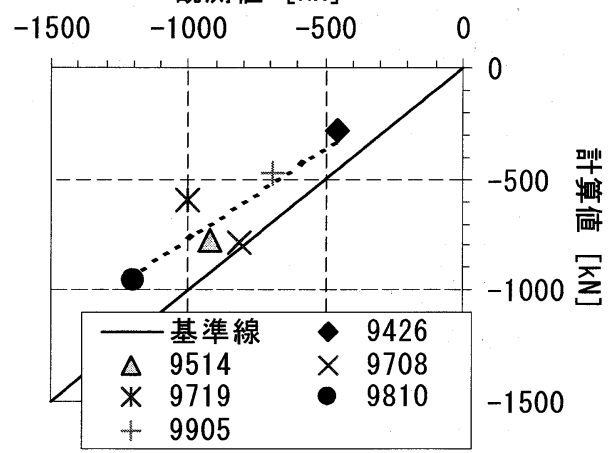

Fig.4 Axial Force of main leg member 9905 号時の最大風速計測時の 10 分間データ対象に, 中 央鉄塔最下節主柱材圧縮軸力の比較した. その結果を Fig.4 に示す. ただし, 架渉線荷重の比較に用いた入力 值は, 風観測結果に基づき, 台風 9807 号時, 乱れの強 さ 0.2 , 吹き上げ角 15 度, 台風 9810 号時, 乱れの強さ 0.3 , 吹き上げ角 20 度とし, 平均風速によらず一定とし た. 一方, 最下節主柱材軸力比較に用いた入力値は, 中 央鉄塔頂部超音波風速計の平均風速，風向で代表させ， 平均風速のべき指数をゼロとした. なお, ディケイファ

夕は 10 , 乱れの強さは日本建築学会建築物荷重指針 従った.

これらの結果から, 架渉線風圧荷重の最大值およびガ 卜影響係数の観測值と計算值は, 台風 9807 号時には 較的よく一致しているが，台風 9810 号時には観測值 方が若干大きめの評価となっている.これらの傾向は, 涉線張力荷重についても同様であった. この原因とし ，台風 9810 号時の風は，台風 9807 号時に比へ，乱れ 強さ，吹き上げ角が比較的大きく，変動風速の 2 乗項 影響や地形による風の非定常性の影響が考えられる. 実，特に示していないが台風 9810 号時には，風圧荷 , 張力荷重とも正規分布から大きくずれており, 張力 重についてはピークファクタも大多数が 5 以上であ た.このように，提案した評価式は，多くの場合設計 としてよい評価值を与えるものの, 台風の種類や地形 よっては誤差を生じる場合があり,この点については 後の課題である.

一方，最下節における主柱材圧縮軸力については, 計 值の方が若干小さめの評価を与えるものの, 全体の傾 としては概ね一致することが確認された. 観測值と計 値に差異が生じた原因としては, 風の乱流統計量の情 不足のため, 入力値として中央鉄塔の観測值で代表さ たこと, 昇降機レールや各種計測機器およびケーブル どの付帯設備を無視したこと等が考えられる. 以上の とを考慮すれば, 今後ともデータの充実, 比較例の蓄 を図る必要があるが, 本風荷重評価法は実用的な精度 有していると考えられる.

\section{. 結 び}

本報告では, 風向に応じた鉄塔・架涉線連成系の動的 果を考慮した風荷重評価法の特徴を紹介した. また四 試験線観測值と本風荷重評価法による計算值を比較 ，その妥当性を明らかにした。

辞

本研究は，「而風設計合理化委員会 (平成 11 年 4 月～平成 14 年 3 月)」, 「而風設計実用化検討会 (平成 14 年 4 月～平成 17 年 3 月) (大熊武司委員長 (神奈川大学)）に抒いて実施したものである. 本研究を実施するにあたりご指導いただいた関係者各位に深く感 謝いたします。

\section{参考文献}

1）大熊武司, 中村秀治, 石川智巳，本楖栄次郎，渡辺敏緒，簙田 明秀, 北嶋知樹 : 風向別風速を用いた送電鉄塔の而風設計法に 関する研究一「送電用鉄塔の風荷重指針(案)」の骨子一, 日本 風工学論文集, 第 98 号, pp.137-150,2004.1 


\section{台風 0221 号下の強風による送電用鉄塔の風応答解析}

Wind Response Analyses of Transmission Towers to the Strong Wind under Typhoon 21st, 2002

大石 祐司 ${ }^{1)}$

Yuji OHISHI ${ }^{1)}$
○北嶋 知樹 ${ }^{2)}$ Tomoki KITASHIMA
三上 康朗 2)

Yasuo MIKAMI ${ }^{2}$
山崎 智之 ${ }^{3)}$

Motoyuki YAMAZAKI ${ }^{3)}$

\section{1. はじめに}

平成 14 年 9 月 27 日に発生した台風 21 号は, 関東 地方に上陸した台風としては戦後最大級と言われ，銚 子地方気象台では 10 月 1 日 21 時 20 分に昭和 12 年の 統計開始以来, 観測史上最大となる $52.2 \mathrm{~m} / \mathrm{s}$ の最大瞬 間風速を記録した。この台風により茨城県潮来市で東 京電力の送電用鉄塔 $(275 \mathrm{kV}$ 香取線および $66 \mathrm{kV}$ 湖南 線）10 基が損壊した（図 1）。このため東京電力では 直ちに事故調査委員会を設置, 学識経験者の参画を得 て, 原因調查を行った。その結果, アーク痕の存在や 目撃情報, 鉄塔基礎部の引き揚げ変位の発生状況など から, 最初に倒壊したのは香取線№.22 であると判断 された。また同鉄塔の倒壊原因は基礎の引き揚げ耐力 が設計耐力を下回っていたためと推定され，これは当 該鉄塔に採用されていた基礎形式（井筒基礎）と現地 地盤に起因する固有の問題であること，他鉄塔は香取 線№.22 鉄塔倒壊によって二次的に倒壊・折損したこ とが明らかにされた。この原因調査の過程において


理化研究委員会」 ${ }^{2)}$ の研究成果を活用し, 鉄塔・基礎 に作用した応力を評価したので，本稿ではその概要に ついて紹介する。

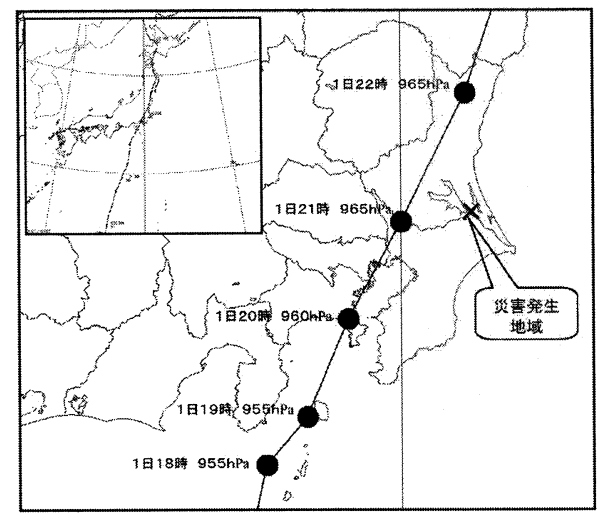

図1 被害発生箇所

\section{2. 風速データの分析}

\section{1 被害筒所および風向風速計の設置箇所}

損壊事故当時の風速データが被害箇所近傍の鹿島線 №.177 鉄塔に設置された風速計で得られている。位置 関係を図 2 に示す。被害箇所の風上となった南側には 水田, 湖が広がっている。

\section{2 観測結果概要}

\section{(1) 風向風速記録}

鹿島線№.177風速計（風車型風向風速計，設置高さ $68.5 \mathrm{~m}$ ，サンプリング時間 0.25 秒）で観測された風向 (16方位) ・風速データを図3に示す。事故直前の主風 向は南であり，観測記録中の最大瞬間風速は，21時12 分に観測された $56.7 \mathrm{~m} / \mathrm{s}$ であった。

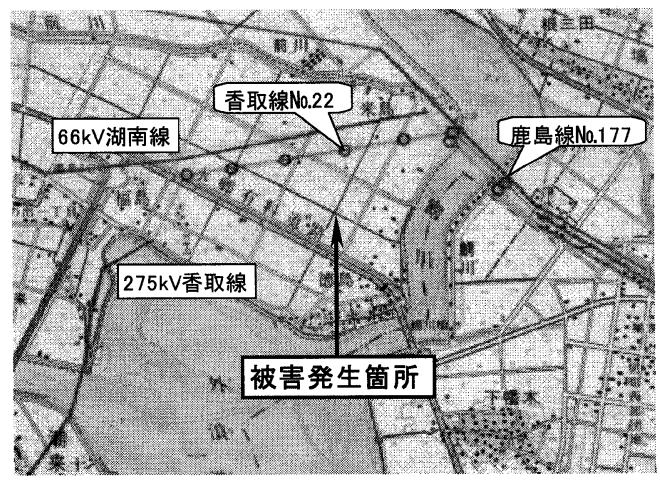

図2＼cjkstart事故箇所と風速計の位置関係

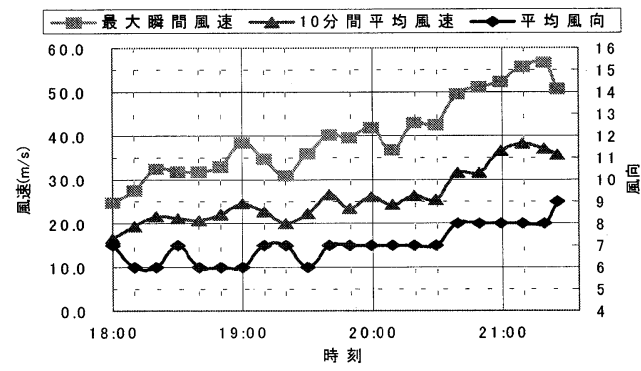

図3 鹿島線№.177風向風速計データ

\footnotetext{
1)東京電力(侏工務部送電グループ

Overhead Transmission Group, Power System Engineering Department, Tokyo Electric Power Company(TEPCO)

2)東京電力株工務部送変電建設センター

Transmission\&Substations Construction Center, Power System Engineering Department, TEPCO

3) 東京電力侏工務部 (財団法人電力中央研究所出向)

Power System Engineering Department, TEPCO
} 


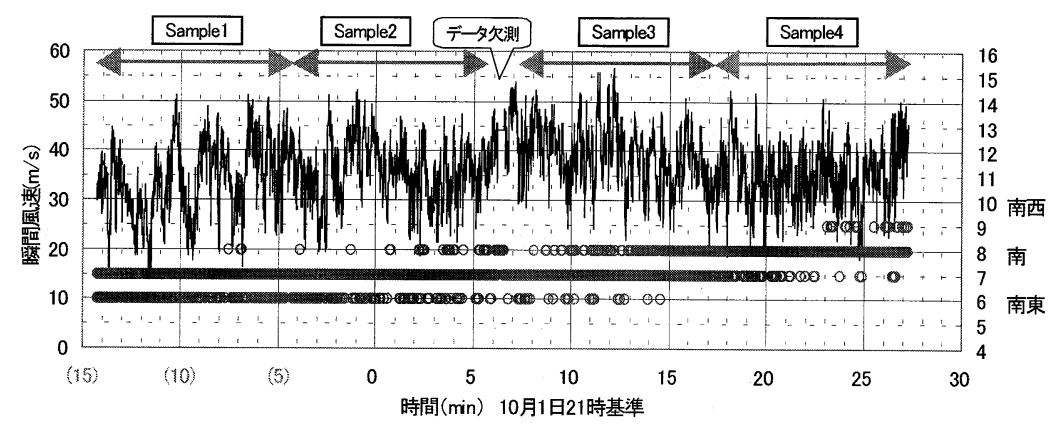

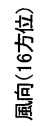

図4＼cjkstart鹿島線№.177風向風速計の時刻歴データ

\section{(2)統計的性質}

図 4 に事故直前の風向，風速時刻歷波形を示す。 21 時 5 分過ぎに停電による欠測がある以外は, 機器は概 ね正常に稼働していたと推定される。図 4 の Sample 毎に風速変動の統計的性質を分析した。結果, 平均風 速は約 $33 \mathrm{~m} / \mathrm{s} \sim 39 \mathrm{~m} / \mathrm{s}$ で, 最大瞬間風速が観測された Sample3 の平均風速が最も高く $39.0 \mathrm{~m} / \mathrm{s}$ であった。ガ ストファクタは概ね 1.5 で, ピークファクタは Samplel を除き 3.0 に近い值であった。乱れ強さは, Sample1 は 0.23，他は 0.16 0.18 程度である。乱れス ケールは Sample1 は 335m，他は $100 \mathrm{~m} \sim 150 \mathrm{~m}$ 程度で あった。

\section{（3）風速変動のスペクトル特性}

図 5 に Sample 毎の風速変動のパワースペクトル密 度を示す。同図には，スペクトルピーク付近を最も良 く近似するように求めた Karman 型スペクトルも合わ せて示した。

\section{3. 台風シミュレーションと風観測データの比較}

鹿島線№.177 で得られた風向風速データの妥当性確 認等を目的として台風シミュレーションを実施した。

\section{1 台風シミュレーション方法}

台風中心から $500 \mathrm{~km}$ 以内に存在寸る気象官署の海面 気圧データを収集し，Schloemerの気圧分布式とBlaton の式により傾度風の風速を求めた。

地上風の風向，風速を算定は石原 $5^{5}$ !の提案している 強風時の大気境界層における鉛直分布特性の数值モデ ルを使用した。

\section{2 台風シミュレーション結果}

\section{(1) 傾度風の風向 · 風速分布}

21 時 10 分における水平方向の分布図を図 6 に示す。 台風進行方向の右側領域では風速 $45 \mathrm{~m} / \mathrm{s}$ 以上の極大域 が被害箇所 (X印) 付近に認められる。

\section{(2) 観測との比較}

シミュレーションと鹿島線 No.177 鉄塔地点とを比 較して, 図 7 に示す。シミュレーションから得られ た風速，風向およびその変化傾向は観測と良く一致 していることが確認できた。
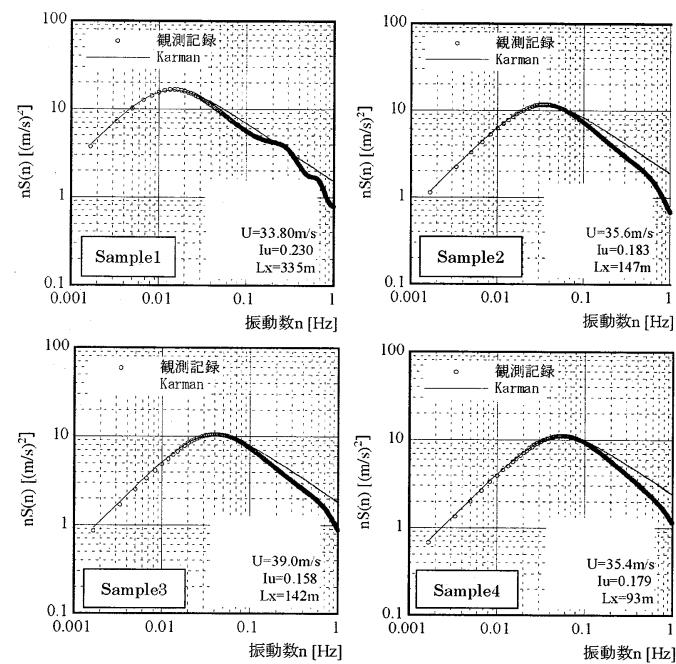

図 5 風速変動のパワースペクトル密度

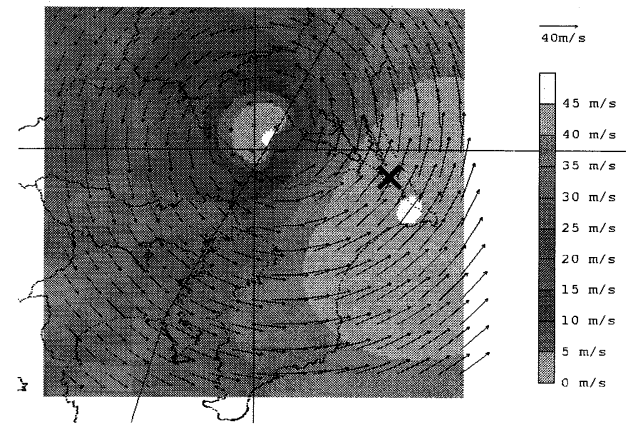

図6＼cjkstart傾度風の風向 · 風速分布 $(21: 10)$
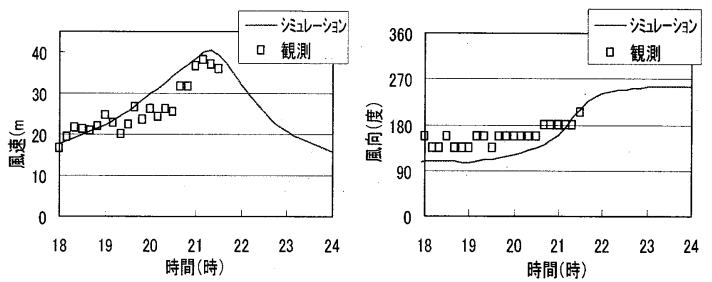

図 7 風向 $\cdot$ 風速の比較（鹿島線№.177） 


\section{4. 気流解析による風速推定}

\section{1 解析方法}

被害箇所の風速推定のため, l-wind ${ }^{6}$ を用いて気流 解析を実施した。解析条件を表 1 に示す。解析にあた り地表面粗度は土地利用デー夕に応じて図 8 のとおり 設定した。

\section{2 解析結果}

解析の結果，以下のことが確認できた。なお解析結 果は鹿島線№.177 風速計位置において Sample3 観測值

（平均風速 $39 \mathrm{~m} / \mathrm{s}$ ，乱れ強さ $0.16 ）$ に一致するよう補 正してある。

\section{(1) 平均風速}

平均風速分布を図 9 に示す。解析領域の右側で粗度 による減速が認められる。鹿島線№.177 鉄塔および香 取線№.22 鉄塔地点の平均風速の鉛直プロファイルを 図 10 に示す。風上側が湖となるNo.22 鉄塔は№.177 鉄 塔に比へ，高さ $50 \mathrm{~m}$ （鉄塔高さの $2 / 3$; 基準高さ） で約 $2 \mathrm{~m} / \mathrm{s}$ 大きい結果となった。

\section{(2) 乱れ強さ}

鹿島線 No.177 鉄塔と香取線 No.22 鉄塔地点の乱れ 強さの解析結果を図 11 に示す。地上 $50 \mathrm{~m}$ 付近では, 香取線 No.22 鉄塔地点の乱れ強さは, 鹿島線 No.177 鉄塔に比べ 0.02 程度小さい。

表 1 解析条件

\begin{tabular}{|c|c|c|}
\hline \multicolumn{2}{|l|}{ 項目 } & 条件 \\
\hline \multirow[t]{3}{*}{ 入力風 } & 風向 & $S$ \\
\hline & $V_{10}($ 粗度 II) & $28.6 \mathrm{~m} / \mathrm{s}$ \\
\hline & 傾度風高さ & $350 \mathrm{~m}$ (地表面粗度 II ) \\
\hline \multirow[t]{2}{*}{ 解析中心 } & 緯度 & $\begin{array}{llll}35^{\circ} & 36^{\prime} & 04^{\prime \prime} \\
\end{array}$ \\
\hline & 経度 & $140^{\circ} 36^{\prime} 48^{\prime \prime}$ \\
\hline \multirow[t]{3}{*}{ 解析領域 } & 水平 & $7 \mathrm{~km} \times 6 \mathrm{~km}$ \\
\hline & 鉛直 & $10 \mathrm{~km}$ \\
\hline & 地表面粗度 & 土地利用データにより個別設定 \\
\hline \multirow[t]{2}{*}{ メッシュ幅 } & 水平 & $50 \mathrm{~m}$ \\
\hline & 鉛直 & $100 \mathrm{~m}$ まで $10 \mathrm{~m}, 10 \mathrm{~km}$ まで対数 20 分割 \\
\hline
\end{tabular}

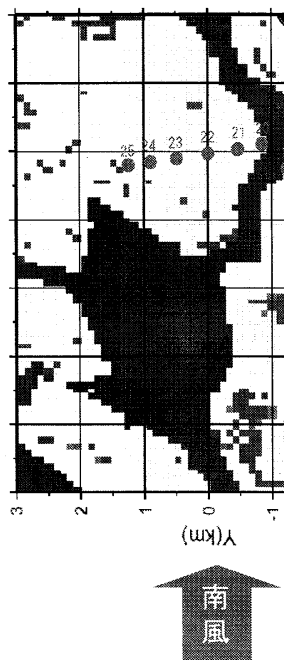

図 8 解析領域の地表面粗度設定

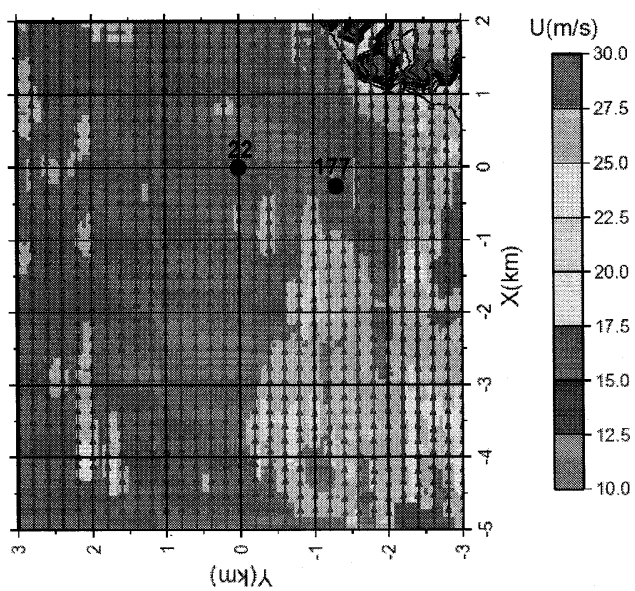

図 9 平均風速水平方向分布（高さ $10 \mathrm{~m}$, 補正前)

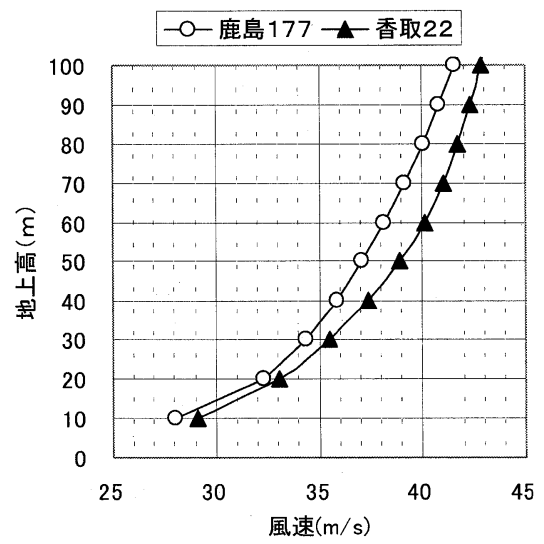

図 10 鹿島線№.177 と香取線 No.22 の平均風速

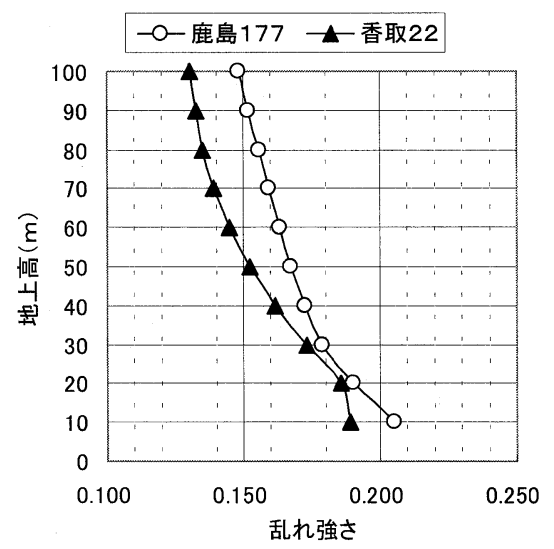

図 11 鹿島線№.177 と香取線№.22 の乱れ強さ 


\section{5. 等価静的風荷重算定および応力解析}

「送電用鉄塔の風荷重指針(案) ・同解説, 2002 年 6 月, 電力中央研究所 (以下, 風荷重指針案)」 $\left.{ }^{2}\right) に よ$ り各鉄塔の等価静的風荷重算定および鉄塔・基礎の応 力解析を行い, 設計耐力と比較した。

\section{1 風の性状の設定}

等価静的風荷重算定に用いた風の性状を表 2 に示す。 平均風速および乱れ強さについては, Casel：鹿島線 №.177観測值（高さ $68.5 \mathrm{~m}$ ）基準とした場合および Case2 : 香取線 $N_{0} 22$ 鉄塔地点解析值（高さ $50 \mathrm{~m} \fallingdotseq$ 鉄塔 高さの2/3）を基準とした場合の2ケースとし，風荷重 指針案の粗度 $\Pi$ の $\alpha=0.15$ を用いて鉛直プロファイル を設定した。乱れスケールおよびディケイファクタは 風荷重指針案に基づいた。

\section{2 検討風向}

検討風向は南風 $\left(180^{\circ} \pm 20^{\circ}, 5^{\circ}\right.$ 刻み: 図 12 参照) とし，実線路走向を考慮して荷重・応力を解析した。

\section{3 検討結果}

鉄塔・基礎の応力は Case2 が Casel を 4 6\% 程度 上回った。主柱材軸力が最大となる風向は，№.22： $180^{\circ}$, №.25: $170^{\circ}$, その他 : $160^{\circ}$ 風向であった。 №22，23 の風向と応力比との関係を図 13 に示す。線 路直交風向（約 $170^{\circ}$ ）に対し, 風向が（長径間側 に）約 $10^{\circ}$ シフトした際に最大值となっていること が確認される。№.22 の部材圧縮軸力(Case2)を送電用 支持物設計標準（JEC127-1979） ${ }^{7}$ に基づく解析值（基 準速度圧 $125 \mathrm{kgf} / \mathrm{m}^{2}$ ) と比較して図 14 に示寸。これよ り, 部材軸力が部材強度（JEC127-1979 に基づく公称 座屈強度）を下回っていることが確認できる。№.22 基礎の最大引揚反力（約 $1700 \mathrm{kN}$ ） は設計地盤降伏支 持力の約 70\%の值であった。

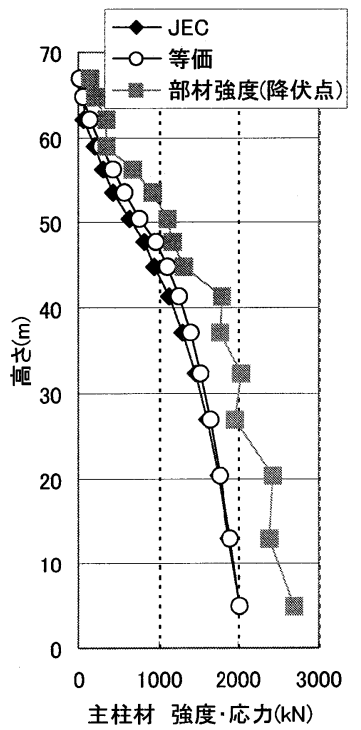

表 2 風荷重解析に用いた風のプロファイル

\begin{tabular}{|c|c|c|}
\hline 検討ケース & Casel & Case2 \\
\hline 平均風速 $\mathrm{Uz}$ & $39 \cdot(\mathrm{Z} / 68.5)^{0.15}$ & $39 \cdot(\mathrm{Z} / 50)^{0.15}$ \\
\hline 乱れ強さ $\mathrm{Iz}$ & $0.16 \cdot(\mathrm{Z} / 68.5)^{-0.20}$ & $0.15 \cdot(\mathrm{Z} / 50)^{-0.20}$ \\
\hline 乱れスケール $\mathrm{Lz}$ & \multicolumn{2}{|c|}{$100(\mathrm{Z} / 30)^{0.5}$} \\
\hline ディケイファクタ & \multicolumn{2}{|c|}{$\mathrm{ky}=\mathrm{kz}=10$} \\
\hline
\end{tabular}

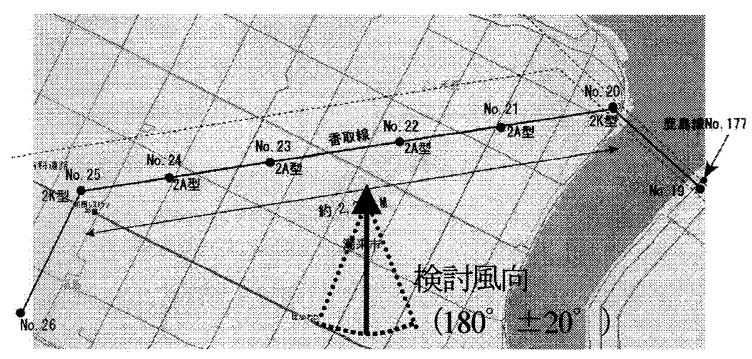

図 12 検討風向

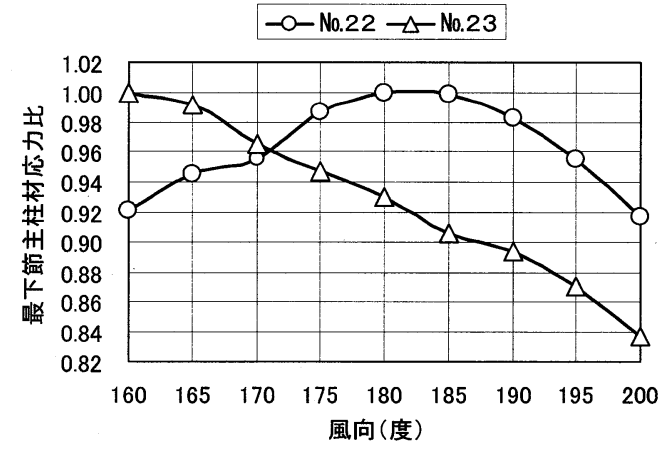

図 13 風向と主柱材軸力との関係（最大值基準）

図 14 №.22 鉄塔強度検討結果 


\section{6. 動的応答解析}

時刻歷風応答解析プログラム $\mathrm{TC}-\mathrm{DAS} \mathrm{S}^{8)}$ を使用して 被害箇所の鉄塔-架涉線連成系の動的応答解析を実施 し, 挙動を確認するとともに等価静的風荷重に基づく 応力解析結果と比較した。

\section{1 解析概要}

解析対象範囲は, No.20〜25 鉄塔を考慮した 6 基 7 径間とし (図 15 参照), No.19 および No.26 鉄塔側架 渉線の支持条件はピン支持とした。鉄塔・架涉線のモ デルおよび境界条件は表 3 のとおり。材料は弾性モデ ルで幾何学的には線形モデルとした。減衰定数は鉄 塔 : 線路直交方向 1 次固有振動数に対し $2 \%$, 電線 :

$1 \mathrm{~Hz}$ で $0.4 \%$ とした。解析は 10 分間 $\times 6$ 回とし, アン サンブル平均により応答の変動值を算定した。入力風 の統計的性質は 5.1 項に示す Case1, 風向は南 (180 ) とした。

表 3 鉄塔および架渉線モデルと境界条件

\begin{tabular}{|c|c|}
\hline $\begin{array}{l}\text { 鉄塔 } \\
\text { (立体骨組) }\end{array}$ & 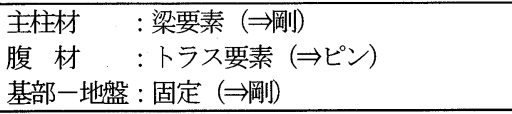 \\
\hline 架渉線 & $\begin{array}{l}\text { トラス要素（径間内 } 30 \text { 要素） } \\
\text { ※電線は } 4 \text { 導体と等価岡性を有する単導体へ } \\
\text { 簡略化，平均風力に対しては幾何非線形を考 } \\
\text { 慮 }\end{array}$ \\
\hline がいし連 & トラス要素 (片側 3 要素) \\
\hline
\end{tabular}

\section{2 解析結果}

解析の結果，以下が確認された。

・鉄塔頂部変位のリサージュ図で最も変位が大きい のはNo.22鉄塔の約 $60 \mathrm{~cm}$ であった。この值は鉄塔 高に対する比率では $0.9 \%$ に過ぎない（図16）。

・主柱材の解析值は等価静的手法による値とほぼ同 等となった。腹材は動的解析值が等価静的手法に よる值を若干上回った。(図17)

・ No.22鉄塔の部材軸力, 基礎反力の解析値はいずれ も設計耐力を下回る結果であった。

\section{7. まとめ}

以上，台風 0221 号による鉄塔損壊事故の原因調査 の過程で実施された風応答解析の結果について述べた。 この強風により，倒壊の起点となった香取線№.22 鉄 塔・基礎に作用した応力は，設計耐力より低い值で あった。なお，倒壊は基礎の引き揚げに対する実耐力 が設計引き揚げ耐力を下回っていたことが原因と判断 されており, 東京電力では本調査結果に基づき, 現存 する同種の基礎全てについて地盤の再調査およひ耐力 評価を行い，必要な補強を実施済みである。

\section{謝辞}

本稿は $275 \mathrm{kV}$ 香取線他の倒壊に伴い, 東京電力が 設置した事故調查委員会で検討された内容の一部を紹

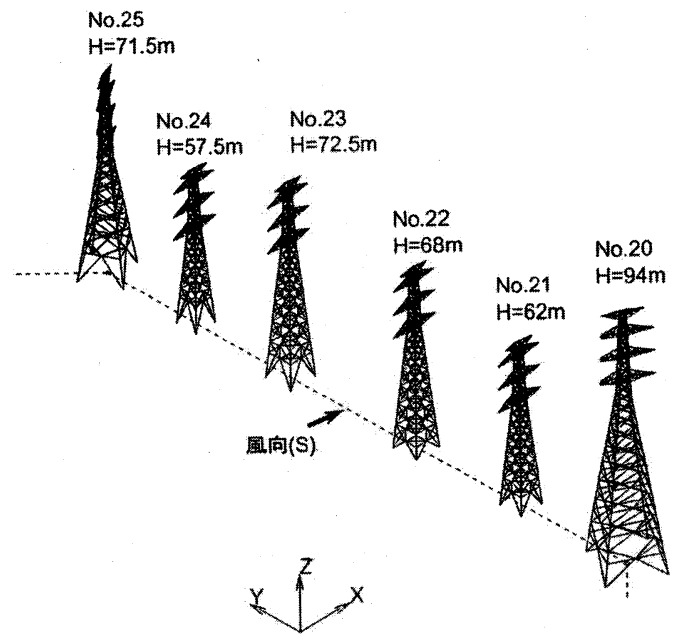

図 15 鉄塔 6 基の立体骨組モデル

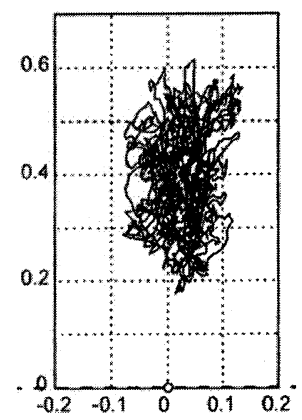

図 16 No.22 鉄塔頂の変位履歴 $(\mathrm{m})$

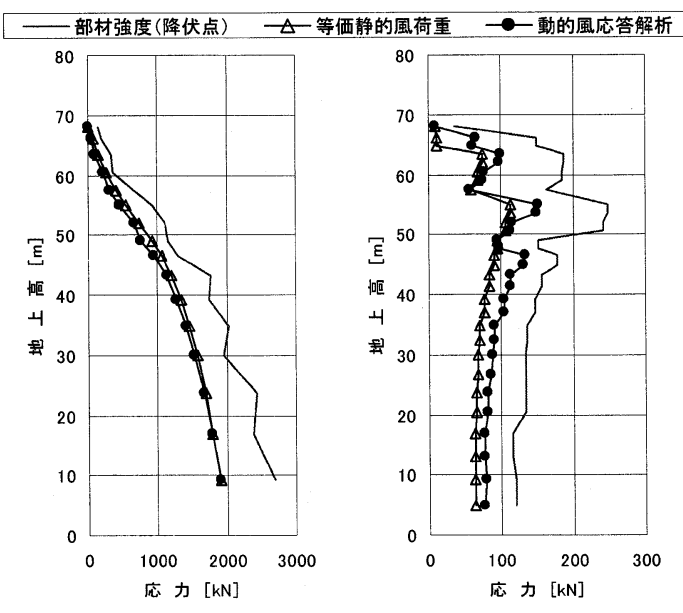

図 17 No.22 動的解析結果（左 : 主柱材，右 : 腹材） 
介したものである。同委員会に顧問として参加頂いた 國生剛治教授（中央大学），田村幸雄教授（東京工芸 大学)，内藤玄一教授 (防衛大学校)，前田潤滋教授

（九州大学大学院）および山岸啓利氏（日本鉄塔協 会）には多数の貴重な意見をいただいた。また動的解 析にあたっては丸川・安井両氏（泉創建エンジニアリ ング）の協力を得た。ここに記して謝意を表します。

\section{参考文献}

1) 大熊武司, 田村幸雄, 山岸啓利, 中村秀治, 石川 智巳, 本郷榮次郎, 箕田義行, 特殊地形における 送電用鉄塔・架渉線連成系の耐風設計に関する研 究（その1）局地風対策研究成果のとりまとめ, 日本風工学会誌 第 82 号, 2000.1

2) 大熊武司, 中村秀治, 石川智巳, 本郷榮次郎, 渡 辺敏緒, 篠田明秀, 北嶋知樹 : 風向別風速を用い た送電鉄塔の耐風設計法に関寸る研究一「送電用 鉄塔の風荷重指針(案)」の骨子一, 日本風工学会 誌 第98号, 2004.1

3）平成13年7月1日 国土地理院発行 50,000分の1 地形図 : 潮来 (縮小)

4) 光田寧, 藤井健 : 台風の確率モデルの作成とそれ による強風のシミュレイション, 京都大学防災研 究所年報第29号B-1, 1986.

5) 石原孟, 松井正宏, 日比一喜 : 中立時の大気境界 層における強風の鉛直分布特性, 日本風工学会誌 第66号, 1996.1

6）中村秀治，田中伸和，中園信，松山彰，友延伸幸 : 特殊地形における送電用鉄塔・架涉線連成系の 而風設計に関する研究 (その2) 特殊地形の簡易 判定法と気流シミュレーションに基づく設計風速 の算定法, 日本風工学会誌 第82号, 2000.1

7) 電気学会 : 電気規格調查会標準規格, 送電用支持 物設計標淮JEC-127-1979

8）安井八紀，丸川比佐夫，大熊武司 : 送電用鉄塔の 風応答解析，日本風工学会誌 第76号，1998.7 